CATALAN REVIEW

Catalan Review

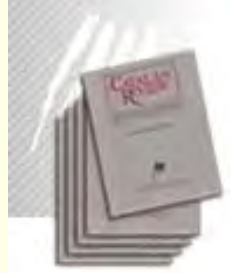

You are accessing the Digital Archive of the Catalan Review Journal.

By accessing and/or using this Digital Archive, you accept and agree to abide by the Terms and Conditions of Use available at http://www.nacs-

catalanstudies.org/catalan_review.html

Catalan Review is the premier international scholarly journal devoted to all aspects of Catalan culture. By Catalan culture is understood all manifestations of intellectual and artistic life produced in the Catalan language or in the geographical areas where Catalan is spoken. Catalan Review has been in publication since 1986 .
NORTH

AMERICAN

CATALAN

SOCIETY
Esteu accedint a l'Arxiu Digital del Catalan Review

A l' accedir i / o utilitzar aquest Arxiu Digital, vostè accepta i es compromet a complir els termes i condicions d'ús disponibles a http://www.nacs-

catalanstudies.org/catalan_review.html

Catalan Review és la primera revista internacional dedicada a tots els aspectes de la cultura catalana. Per la cultura catalana s'entén totes les manifestacions de la vida intel lectual i artística produïda en llengua catalana o en les zones geogràfiques on es parla català. Catalan Review es publica des de 1986.

Writers, Wantons, Witches: Woman and the Expression of Desire in Rodoreda Geraldine Cleary Nichols

Catalan Review, Vol. II, number 2 (1987) p. 171-180 


\title{
WRITERS, WANTONS, WITCHES: \\ WOMAN AND THE EXPRESSION OF DESIRE IN RODOREDA
}

\author{
GERALDINE CLEARY NICHOLS
}

If we where pressed to order the profusion of female characters who animate Mercè Rodoreda's fiction, we might divide them in two groups: the innocents or victims and their opposite number, for which English at least has no ready-made label. Winner? Survivor? The Catalan word triomfadora comes closer to describing characters like Teresa Goday, Cecília $\mathrm{Ce}$, Amanda, Sofia, and Natàlia/Colometa. ${ }^{\mathrm{I}}$ All of them begin as ingenues but are saved from Aloma's or Maria's sad fate by a particular character trait: they are willful women. Women, in other words, who sooner or later impose the shape of their desire on the world around them. This is precisely what writers strive to do: to voice their desire, to impress it on the page and the world that reads it. In a metaphorical sense, all of Rodoreda's triomfadores may be seen to be writers, women who have seized control of the signifier. Natàlia/Colometa becomes a literal writer in the precise moment when she takes control of her own life, carving "Colometa", the name her husband had imposed on her, on the door of their old home, She thus stakes claim to both name and abode, turned grave and gravestone by her word, by her wish.

The relationship Rodoreda perceived between triomfadores, writers and other willful women is made particularly clear in her short stories. To trace her thoughts on this metafictional and selfreferential issue we turn then to four of these stories: "Abans de

${ }^{\text {I }}$ Carme Arnau divides the women in Aloma into two groups which correspond roughly to mine, although her terms seems less appropriate for the later heroines. She calls them the femme fatale or "dona-tirà" (Coral and Violeta) and the "dona-víctima" (Aloma and Anna), Introducció a la narrativa de Mercè Rodoreda: el mite de la infantesa, Barcelona, Eds. 62, 1979, 65. 
"La salamandra", and "Paràlisin. ${ }^{2}$ This small corpus broadens spectacularly the metaphorical reach of "willful women" by incorporating two new models into the paradigm: witches and wantons. As voicers or actualizers of desire, the witch and the hussy flout universal cultural norms mandating silence and sexual repression for women. In this regard they are like the woman writer, a startling comparison made repeatedly in the stories. Inserting the relatively unknown figure of the writer into the signifying chain with such well-known (negative) stereotypes as the witch and the hussy is an elegant way of telling us a great deal about scribbling women. Like her sisters-in-sin, the woman writer is regarded as a pariah; and like theirs her activity is somehow closely linked to her sexuality, making it doubly censurable. But she also has access to their source of power, so feared in patriarchal societies and so repressed over the centuries. In these brief stories Rodoreda traces repeatedly the mysterious connection which exists between women's bodies and their words and their force. When in the midst of a fever of creativity she wrote exultingly to Anna Murià: "penso fer contes que faran tremolar Déu", she synthesized the notion that the woman in full possession of the word - and her desire - could change the world order. ${ }^{3}$ Reading her words, the contemporary feminist recalls Hélène Cixous's similar boutade: "Let the priests tremble, we're going to show them our sexts!n. ${ }^{4}$

The four stories considered here reflect different moments of Rodoreda's thought on the interconnected subjects of writing, desire and social control, all burning issues for a woman author shunned by her fellow exiles for her liaison with Armand Obiols, a married man, would-be writer, and exile like herself. She formu-

${ }^{2}$ All page references will be given in the text, and are based on Mercè Rodoreda, Tots els contes, Barcelona, Eds. 62, 1979.

${ }^{3}$ Letter dated 13 March 1946. Mercè Rodoreda, Cartes a l'Anna Murià 19391956, ed. Isabel Segura, Barcelona, la Sal, 1985, 70.

${ }^{4}$ In "The Laugh of the Medusa", cited in New Frencb Feminisms: An Anthology, Amherst, Mass., U. of Massachusetts P., 1980, 255 . 
lates the two characterological options open to women - innocent or triomfadora - in "Abans de morir", and she restates them in "La salamandra", structuring both works around a love triangle, with the two types of women facing off in a fight over a single man.

The protagonist of "Abans de morir", Marta Coll, is the narrator of her own story, written as a last will, and testament of her victimization. She has other, more sinister and willful motives for writing as well, but these are very sagely concealed until the end of her pathetic tale, by which time the reader's sympathies are fully with her. Her story begins - it was ever thus - on the day she meets the man she will marry. Before he appears she is seated in a café preparing to write a letter, but her pen falls to the floor and breaks, so she is unable to get [a] word out before Màrius and his talismanic briefcase insert themselves in the blank space beside her. Thenceforth the insignificant-looking but wordy-wise Màrius - a lawyer, what else? - will speak the girl's mind and script her life. Her reaction to this territorial invasion is to tip her drink over on him, and not apologize. Ignoring this silent message, rendering it in-significant, Màrius excuses the act as if it were the result of clumsiness. He thereby puts his label on her activity, a tactic he uses repeatedly in the first weeks until she simply gives up trying to express herself. Since she has not mastered the knack of signifying - dropped pen, aborted letter; spilled drink, unacknowledged insult - she is not heard, she cannot impress. Instead of willing, we might say, she wishes. The Rodoredian ingenue does not know her own will any more than does her own body, and that double, synergetic ignorance is often her undoing; she may be inscribed at will by others.

In both "Abans de morir" and "La salamandra" the young women are characterized as loners with their own peculiar universe and interest; they are orphans, and very poor as well, which is to say they are overencoded as defenseless. ${ }^{5}$ Màrius, with three attri-

s The young girl over-characterized as victim is almost inevitably an orphan. Nancy Miller describes the significance of the girl orphan as stock character in fe- 
butes of power, is redundantly marked in the opposite sense: he bears the standard anatomical signifier of power; he is wealthy; and he is a professional wordmonger. He uses all three signifiers to "overpower" Marta, but we are especially interested in his use of the word. His close connection to this signifier is marked in the texts by his briefcase, "la cartera que mai no abandonava" (I58). This object appears to function as a straightforward Piercean indexical sign; if we decode it conventionally, we assume that Màrius' portfolio contains important documents written by him; testaments, should they be necessary, of his discursive prepotency. In fact this is not the case; his particular power pack, as Marta discovers to her horror, is filled with a woman's letters. Since these are the expression of the desire or sexuality felt by a quintessential triomfadora - rich, self - confident, sexually experienced and very willful - they are the most powerful words in the world, tapping into the fearsome force of the feminine. The writer of these letters was Màrius' great love, Elisa, a married woman who used him while her husband was incapacitated. Not simply a wanton, Elisa was also a witch, like Circe, with the power to turn men into beasts: "Va fer canviar el senyoret com una mitja. Ell (...) com va canviar, Senyor (...) Quan ella era fora (...) semblava una bèstia malalta” ( 1655$)$.

The discovery of these letters causes Marta to become aware of the gap between what she has - Màrius' affection - and what she wishes she had - his deepest love. In that gap desire is born, a desire or lack which propels her into the Symbolic Order; it first and last makes a writing woman out of her, and in between, a wanton: "Vaig bastir una novella al voltant d'aquestes cartes" (Is8). She becomes obsessed with j'ossessing the mysterious letters, as though their magic might be transferable, might make her

minocentric fiction in The Heroine's Text: Readings in the French and English Novel, $I 722-1782$, New York, Columbia U.P., 1980, 5. On the use of orphans in Rodoreda, see G. Nichols, "Sex, the Single Girl, and Other Mésalliances in Rodoreda and Laforets, Anales de la Literatura Española Contemporánea, 12 (1988), forthcoming. 
signify as well. She steals a few of them, to read and reread, trying to understand the connection between sex and text: "vaig passar una setmana a casa, entre el llit $i$ la biblioteca... Aviat només vaig viure amb una obsessió. Conèixer aquella dona" (I62). She decides to seek out the origen of this powerful discourse of desire, the "transcendental signified" in Derridian terms: meaning itself as vouchsafed through or in the voice (presence) rather than in writing (absence). ${ }^{6}$ Not surprisingly, Elisa's voice is the most seductive aspect of her overwhelmingly seductive persona. "Una veu (...) Sí, la veu sobretot... Es pot estimar una dona només per sentir aquesta veu" (I64).

Desperate to overwrite this woman, to turn her into a dead letter, Marta makes herself over physically, but she only succeeds in having Màrius' friend, Roger, fall in love with her. An innocent can transform herself into a triomfadora, as Rodoreda repeatedly shows in her fiction, but rarely within one relationship; the victimizer has to disappear for the woman to establish a more advantageous situation for herself with another man. ${ }^{7}$

Marta then makes herself over sexually: "Perquè no pensés en ella, perquè no pensés en les cartes, em vaig posar a estimar-lo desesperadament. Com si cada nit d'amor fos la darrera" (I67). But it is futile; the shadowy traces of that one quintessentially significant voice, as though it incarnated the essence of desire in the world, is far stronger than Marta's febrile lubricity. Finally, she turns once again to writing. The story she leaves - a collage of genres, cut and pasted together - reflects all of her textual/sexual inexpertise. In the last pages, she addresses the text to Roger: «Ha-

${ }^{6}$ See Toril Moi's recapitulation of the Derridian analysis of the Western philosophical tradition, a "metaphysics of presence", which privileges speech over writing. Sexual/Textual Polítics, London, Methuen, 1985, 105-107.

${ }^{7}$ Above all, a woman will never have the upper hand - or even a fair shake in a relationship where the man does not profoundly desire her, i.e. want her as that which he cannot have. If he can possess her easily, either sexually (Aloma) or symbolically, by imposing his script or name on her, he will quite logically not "desire" her (Colometa, Cecília). 
via començat escrivint aquesta història per a mi, però l'acabo per a vós. Perquè m'heu estimat" (167). Her desperate, desire-laden words will inscribe her in the adoring Roger's conscience, just as Elisa's did with Màrius. But Marta learned the secret inscribed in the letters too late to be able to "mean" anything to Màrius, and so she avails herself of a different kind of magic to affect him. Having heard that the last wish of a suicide always comes true, she asks Roger to give Màrius the letters: "Sé que aquestes cartes li cremaran les mans. És tot el que vull" (170). Her last, sinister desire will be realized.

"La salamandra" is a more literary version of the same tale, less metafictional and less patently autobiographical. Its first half echoes the myth of Apollo and Daphne, while the second is reminiscent of Kafka's "Metamorphosis". The protagonist is an orphan who, like Daphne, prefers the woods to human companionship. When a man appears and begins to pursue her, she has no father to turn to for protection, and so he "has his way" with her. When he returns for more, she offers only a token of resistence, a few words spoken too late: «Amb la llengua gelada per l'angúnia, li vaig preguntar: i la teva dona? I ell em va dir: la meva dona ets tu; només tu" (238). When she next opens her eyes, the wife is staring down at them both: "em va agafar pels cabells i em va dir: bruixa" (238). This is not the epithet the reader expects, but its surprising substitution for "slut» leads us to see their interchangeability as terms for the female pariah, the unattached woman universally perceived as a threat to the social order. The wife uses the term most effective in her historical moment for dealing with this sort of threat; soon thereafter, the girl is led away to be burned at the stake. Before she reaches this dramatic moment, however, she and her lover meet wherever they can; imprinted with his desire, she has become a wanton. If she is a witch, he has bewitched her; if she has changed, he is the agent of change: uem vaig adonar tot d'una que ja no esperava res; vivia tot girada enrera amb ell a dintre meu com una arrel dins la terra» (239). Her transformation into a salamander parallels Gregor Samsa's into a beetle: both are 
fantastic events which may represent the actualization of their own or others' perceptions of them as repugnant illicit desirers. The girl's metamorphosis - besides suggesting that all women in love have to learn survive trials by fire - allows her to survive the flames. Within the system of signs established by the tradition of the witch hunt, her survival could also be taken as a divine sign that she is not guilty of witchcraft. At any rate, she and Gregor both become the victims of clean-up drives, and both die pathetically alone.

In "Una carta" all three paradigms of willful women are once again incarnated in a single person, but this mature woman is now the protagonist, and not the antagonist, of the work. The story takes the form of a letter this woman has written to a doctor, ostensibly to ask him for a diagnosis of her "mal". She warns him that she will sign the letter with a pseudonym, although she is aware that it is foolish to call his attention to something he might never notice otherwise; moreover, she thinks he could figure out who she is if he were to put his mind to it. If he were to guess her identity, however, she would deny whatever he might say. All of this shadowboxing around the writer's identity and her name as well as her explicit disposition to lie or otherwise deny the truths anyone might discover about her makes it evident that this tale borders some sensitive territory, tells some truths the writer-Rodoreda - would deny if asked about them point-blank. It is not difficult to see that "Una carta" is also about writing itself, although the writer's coyness makes this less obvious than is the case in "Paràlisi", a sort of thematic sequel to "Una carta". In "Paràlisi» the protagonist is a writer by profession, just like Rodoreda, but she is careful to try to convince the reader that fictional "truths" are never revelations on the part of the author. She forbids us to think that the problems explored in this terrible story are those of its actual author. She writes:

Parlo de mi. I no parlo gens de mi. Quan algú molt intelligent dirà: Ja la tenim amb totes les seves astúcies d'escriptor que vol i no arriba (...) i com confessa, Se- 
nyor (...) es trobarà amb les mans buides. No donaré res. Parlaré sense parar de mi i no donaré res. (...) les mans quedaran buides perquè la veritat no la diu ningú (324).

The protagonist of "Una carta" is unusual in the Rodoredian typology because she has evolved from innocent to triomfadora while in a relationship with the same man. When they married she was so innocent "que al cap d'un any de casada era ben verge, $i$ els crits que em va costar" (I87). She gradually came to wear the pants in the family: "per força, senyor metge, no pas per gust" (188). She attributed her ascendency over him to her greater practicality, but in fact it was due to something mentioned early in the description of her marriage, in parentheses: $"$ (jo era la rica i ell el pobre)" (187). When the woman has the money in the family like Sofia with Eladi - all the ground rules change.

The malady she describes is not physical: she has somehow acquired the power of realizing her desires; even her thoughts materialize. It all began one morning when she looked angrily at her husband and thought to herself: "així et rebentessis». Within the quarter hour, he was dead. Widowed, wealthy, and young enough to experience desire, this is a woman at the height of her power; the disconcerting transformation of her thoughts into "reality" (the fictional reality she creates in her letter) is another way to represent her connection to this numinous female force. The transformations are not fantastic, unless we take this story to be referential: they are a metaphoric description of successful writing. Her last experience - a nature epiphany, so typical in women's literature - makes this connection clear, because it is clearly words that materialize:

I sense gairebé pensar, només pensava paraules: flors, pomeres, pomeres florides de blanc (...) I vaig pensar que seria bonic de veure una pomera al mig del mar. (...) I a l'últim, totes plegades, [les bombolletes] van anar fent una pomera. Imagini, una pomera florida al pic de l'estiu i dintre del mar (19I).

When she goes out to touch the tree - so lifelike! - she nearly 
drowns. At that point she realizes that the power of her imagination has moved beyond the pale of normalcy, and she appeals to the doctor for help. She herself has come to a provisional diagnosis of her malady, revealed in the last line of her letter: «Em penso que sóc bruixa". It is an abrupt and unexpected and unsatisfying closure, because the sort of symptoms she has described are not what one generally associates with witches. The signifier does not fit the signified. Or does it? Women with extraordinary and littleunderstood powers have been called witches for centuries. Women writers have such powers, the writer of this letter/story among them. Perhaps they too should be understood as witches.

"Paràlisi" is protagonized by a more conventional writer, but one who seems to be losing her force. "Al bell mig de la vida", she is past that imperceptible line which Rodoreda described in an interview, "una mica més enllà de la trentena", when the woman realizes "que va passant a poc a poc de fada a bruixam. ${ }^{8}$ Words are failing her. She plans to seduce her doctor, but as she dresses for her appointment with him she cannot find a slip that she is sure will make all the difference, like a magical amulet: "On deu ser aquest dimoni de combinació blava? Si no la trobo estic perduda". She cannot find the right words to attract him, or to finish the story she has in her typewriter; her companion has taken another lover. A blocked writer, a witch only by virtue of her age, and a failed wanton, this protagonist shows that a woman's power can evaporate if she stops listening to her own voice and attends to the world's, which alternates burning little old hags at the stake with simply despising them into silence.

It should not surprise us that Rodoreda's vision of a woman's power, based on her sexuality and her more or less successful projection of desire onto her surroundings, changed as she aged. The impatience of a Marta Coll, or the destructive sexual absorption of the Daphne figure in "La salamandra", were transmuted in later protagonists into greater self control and tranquility (Teresa,

${ }^{8}$ Baltasar Porcel, «Mercè Rodoreda o la força lírica», Serra d’Or (1966), 75. 
Amanda, Natàlia, Cecília, the letter-writer). The self-pitying and seemingly powerless writer of «Paràlisi» - if she was a simulacrum of Rodoreda - was merely passing through another stage of development. The fiction Rodoreda was to write after "Paràlisi" Quanta, quanta guerra and La mort i la primavera - would have little in common with the earlier projection of her desire. And if at some moment in her life, like the writer of "Paràlisi", she keened the loss of her sexual power over men, Rodoreda's power over the word is a battle she never lost, as our presence here today testifies. 